\title{
Viscosity of seawater controls beat frequency of water-pumping cilia and filtration rate of mussels Mytilus edulis
}

\author{
Hans Ulrik Riisgård ${ }^{1, *}$, Poul S. Larsen ${ }^{2}$ \\ ${ }^{1}$ Marine Biological Research Centre, University of Southern Denmark, Hindsholmvej 11, 5300 Kerteminde, Denmark \\ ${ }^{2}$ Department of Mechanical Engineering, Fluid Mechanical Section, Technical University of Denmark, Building 403 , \\ 2800 Kgs. Lyngby, Denmark
}

\begin{abstract}
The small-scale movements of cilia make the temperature-dependent viscosity of water a key physical/mechanical factor. In mussels and other suspension-feeding bivalves, bands of waterpumping lateral cilia produce the feeding current through the interfilamentary canals of the enlarged gill (which mainly serves as a water-pumping and food-particle collecting organ). Because the viscosity of seawater is inversely related to temperature, the linear increase of filtration rate with temperature in mussels cannot be explained solely by increased biological activity. To resolve the question of whether change in filtration rate with temperature in mussels Mytilus edulis is under mainly biological/physiological or physical/mechanical control, we conducted laboratory experiments on mussel-gill preparations stimulated with serotonin, and on intact mussels. In gill-preparations, the beat frequency of the water-pumping lateral cilia was measured both as a function of temperature and as a function of kinematic viscosity in dextran- and PVP-manipulated seawater at constant temperature. Data on kinematic viscosity of seawater and viscosity-manipulated seawater were converted to 'temperature equivalents' of seawater by measurement of the viscosities, and this showed that the effect of temperature on lateral cilia activity in gill-preparations is purely mechanical, controlled by the viscosity of the ambient seawater. Further, the ciliary beat frequency was found to depend on kinematic viscosity to the power $-3 / 2\left(f \approx \mathrm{v}^{-3 / 2}\right)$, a relation we used to develop a musselpump model for the filtration rate of intact mussels vs. viscosity. The model is in agreement with filtration rates measured in intact mussels, suggesting that viscosity of seawater is the controlling factor for the beat frequency of lateral pump-cilia and filtration rate in mussels. According to the model, the mussel pump yields a constant power within the temperature-tolerance interval.
\end{abstract}

KEY WORDS: Beat frequency $\cdot$ Lateral cilia $\cdot$ Kinematic viscosity $\cdot$ Dextran $\cdot$ PVP $\cdot$ Filtration rate Mussel-pump model

Resale or republication not permitted without written consent of the publisher

\section{INTRODUCTION}

In the temperature-tolerance interval, within which ciliary suspension-feeding bivalves keep their valves fully open, the relationship between temperature and filtration rate is approximately linear (Jørgensen et al. 1990, Riisgård \& Seerup 2003, Kittner \& Riisgård 2005). Further, there is a general lack of temperature compensation in bivalves examined experimentally (Jørgensen et al. 1990, Petersen et al. 2003, Riisgård \& Seerup 2003,
Kittner \& Riisgård 2005). Lack of physiological compensation implies that bivalves do not achieve temperature independence through complete physiological acclimation of the filtration rate following transfer to a higher or lower constant temperature, although this acclimation mechanism was suggested by Widdows \& Bayne (1971), Widdows (1976, 1978), and Bayne (1998).

It is obvious that the filtration rates of mussels must be correlated to the beating activity of the water pumping lateral cilia on the gill filaments. The inner- 
vations of the $15 \mu \mathrm{m}$ long lateral cilia are both cilioexcitatory serotonergic and cilio-inhibitory dopaminergic, and the nervous regulation of the activity of the lateral cilia is complex (Aiello 1960, Jørgensen 1975, Jørgensen \& Ockelmann 1991). Whether mussels finetune the beat frequency of the lateral cilia as a regulatory response to ambient temperature remains unknown (Riisgård 2001a).

The metabolism of poikilothermic animals generally increases with increasing temperature, but the linear increase of filtration rate with temperature in the blue mussel Mytilus edulis and other ciliary suspensionfeeding bivalves (Kittner \& Riisgård 2005) cannot be explained solely by increased biological activity of the lateral cilia, because the viscosity of seawater is inversely related to temperature. The lateral cilia provide the power that drives the water flow through a mussel, but for cilia operating at very low Reynolds numbers, and for flows through narrow conduits, the viscosity of the ambient water exerts a crucial mechanical effect (Jørgensen et al. 1990). The hydrodynamic scale is characterized by the dimensionless Reynolds number $(\mathrm{Re})=$ object length $(l) \times$ velocity $(u) /$ kinematic viscosity of seawater $(v)\left(\sim 10^{-6} \mathrm{~m}^{2} \mathrm{~s}^{-1}\right)$, which indicates the relative importance of inertial and viscous forces (Purcell 1977, Jørgensen 1983, Sleigh 1989). In mussels, the mean velocity $(u)$ of the cilia driven through current is about $1 \mathrm{~mm} \mathrm{~s}^{-1}$, and the length (l) of a solid perpendicular to the flow is given by the diameter of the lateral cilia $(0.2 \mu \mathrm{m})$, and thus $\operatorname{Re}=l u / v=0.0002$. Other length scales, such as the width of interfilament canals $(40 \mu \mathrm{m})$, also lead to $\operatorname{Re}<<1$, hence viscous forces dominate. Cilia driven flows, forces acting on beating cilia, and major contributions to the flow resistance through the mussel all increase with increasing kinematic viscosity. Therefore, the effect of temperature-dependent viscosity is highly relevant to a better understanding of the physical basis of ciliary suspension feeding in aquatic organisms.

A certain increase in viscosity by either temperaturechange or by addition of a high molecular weight polymer (dextran) at constant temperature causes a strong reduction in the ingestion rate of particles in ciliary suspension-feeding larvae of the sand dollar Dendraster excentricus, but only about $50 \%$ of the reduction is thought to be attributable to viscosity change (Podolsky 1994). Similar observations were made on trochophore larvae of the serpulid polychaete Galeolaria caespitose (Bolton \& Havenhand 1998). Clearly, the ingestion rate of particles depends on both the pumped volume flow (filtration rate) and the particle capture process. To separate the two, and to resolve underlying basic mechanisms, the present study set out to measure beat frequency of the lateral cilia in mussel-gill preparations (using video-microscope recordings) and to measure filtration rate of intact blue mussels in response to the effects of temperature, and manipulated viscosities at constant temperature. Such results should also aid the development of an improved ciliary-pump model for an intact mussel.

\section{MATERIALS AND METHODS}

Video-observations. All video-microscope observations were made at the Marine Biological Research Centre, Kerteminde, Denmark on locally collected blue mussels Mytilus edulis. The mussels were kept in aerated seawater $\left(20^{\circ} \mathrm{C}, 20\right.$ psu) until videomicroscope recordings could be made. Paths of algal cells were studied using the observation vessel submerged-microscope objective technique of Nielsen et al. (1993), Riisgård et al. (1996), and Riisgård \& Larsen (2005). Gill-filament preparations were isolated in an approximately $10 \times 10 \mathrm{~cm}$ temperature-controlled microscope observation vessel filled with seawater to a depth of $2 \mathrm{~cm}$. The gill preparations were fixed $1 \mathrm{~cm}$ above the bottom by means of clips attached to 2 movable (rotational and translational) rods, leaving approximately $1 \mathrm{~cm}$ of seawater above the free surface of the gill filaments. The vessel was placed on a microscope stage (Nikon with $60 \mu \mathrm{m}$ depth of focus at $40 \times$ magnification) with the cross-table removed so that the microscope objective could be immersed in the water above the gill preparation, which was illuminated through a thin glass window in the bottom of the chamber. The objective was sufficiently far (6 to $7 \mathrm{~mm}$ ) from the gill filaments not to affect the rate and direction of flows.

Ciliary beat frequency and effect of 5-HT. The metachronal waves of lateral cilia, moving in opposite directions on 2 adjacent filaments were observed and recorded using a video camera (Kappa CF 11/1) attached to the microscope, and a 50 half-frames-per-second video recorder (Panasonic NV-FS200 HQ). The wavelength $(\lambda, \mu \mathrm{m})$ was determined as the distance between 2 wave crests; the wave speed $\left(c, \mu \mathrm{m} \mathrm{s}^{-1}\right)$ was estimated on the basis of the distance a wave crest had moved during $0.2 \mathrm{~s}$ (10 half-frames). We subsequently estimated the lateral cilia beat frequency as: $f=c / \lambda$, using mean values of 10 determinations of both wavelength and wave speed. In isolated Mytilus edulis gill filaments, the frequency of beating of the lateral cilia decreased soon after preparation. The cilio-excitatory effect of 5-HT (5hydroxytryptamine; serotonin) on isolated gill filaments is depicted in Fig. 1. The beat frequency of the lateral cilia increased from $14.0 \pm 0.5$ (SD) Hz at a concentration of $10^{-7} \mathrm{M} 5$-HT in the surrounding water $\left(18^{\circ} \mathrm{C}\right)$ to $16.6 \pm$ $0.3,20.0 \pm 0.1,24.6 \pm 0.4$, and $26.6 \pm 2.7 \mathrm{~Hz}$ at final $5-\mathrm{HT}$ concentrations of $5 \times 10^{-7}, 10^{-6}, 5 \times 10^{-6}$, and $10^{-5} \mathrm{M}$ in the 


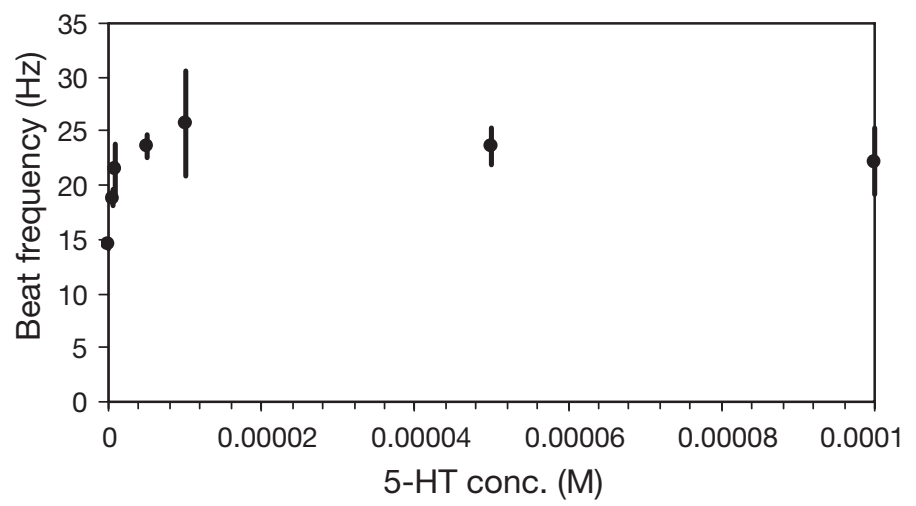

Fig. 1. Mytilus edulis. Mean $( \pm 2 \mathrm{SD}, \mathrm{n}=8)$ beat frequency of lateral cilia in gill preparation $\left(18^{\circ} \mathrm{C}\right)$ stimulated with different concentrations of 5 -HT in seawater (20 psu)

microscope observation vessel, respectively. At higher 5-HT concentrations there was no further stimulation, but a slight tendency for decreased beat rate with increasing concentration. It appears that 5-HT is highly potent in stimulating the activity of the lateral cilia on the gill filaments of Mytilus edulis when added to the surrounding water (Jørgensen 1975). Maximal stimulation of the lateral cilia was obtained at about $10^{-5} \mathrm{M} 5$-HT. At this concentration, the laterofrontal cirri were also overstimulated and thus removed from the interfilament canal (Jørgensen 1975, Jørgensen et al. 1988, Nielsen et al. 1993, Riisgård et al. 1996). Therefore, $10^{-5}$ M 5-HT was adopted as a standard treatment in subsequent video-microscope experiments with gill-preparations in which the beat frequency of lateral cilia was studied as a function of seawater (20 psu) temperature in the observation vessel (regulated step-wise up and down using a Lauda RE 04 heater/cooler system).

Viscosity measurements. Seawater: The kinematic viscosity of 20 psu seawater was measured as a function of temperature using a calibrated viscometer (Ubbelohde Viscometer fitted with a tempering jacket; Schott). Measured kinematic viscosity as a function of temperature is shown in Fig. 2 along with table-values for 35 psu seawater obtained from Rawson \& Tupper (1968). The temperature data in Fig. 2 (denoted 'temperature equivalents', Te) plotted as a function of kinematic viscosity $(v)$ can be described by the power trend line shown in Fig. 3, and the fitted equation has been used subsequently in the present work.

Dextran: The viscosity of dextran-manipulated seawater $\left(v_{\mathrm{d}}\right)$ was measured at constant temperature $\left(22^{\circ} \mathrm{C}\right)$ using an Engler viscosimeter and applying the equation: $v_{\mathrm{d}}=v_{\mathrm{w}}\left(\Delta t_{\mathrm{d}} / \Delta t_{\mathrm{w}}\right)$, where $v_{\mathrm{w}}=$ viscosity of seawater, and $\Delta t_{\mathrm{d}}$ and $\Delta t_{\mathrm{w}}$ are the flow-through time for seawater with added dextran (D4772 Blue Dextran, mol wt. 2000000 ; Sigma-Aldrich) and clean seawater (20 psu), respectively. Concentrations of $0.75,0.68$,

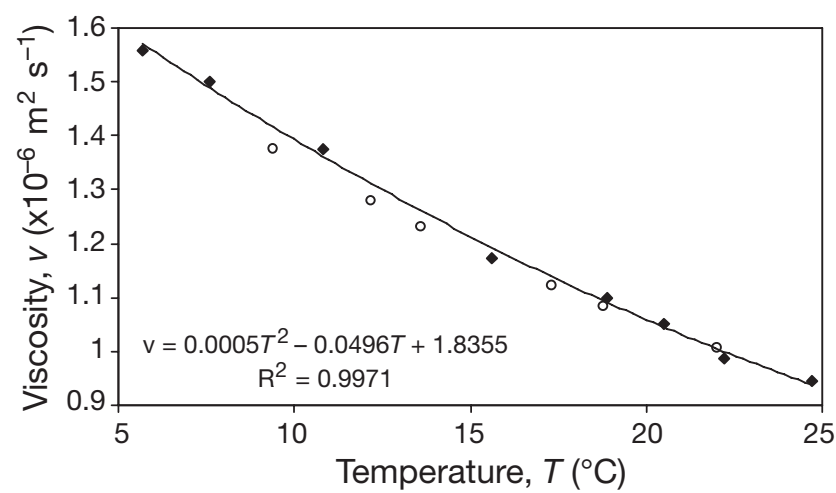

Fig. 2. Measured kinematic viscosity (v) of 20 psu seawater as a function of temperature $T$. ( ) Table-values for kinematic viscosity of $35 \mathrm{psu}$ seawater at different temperatures (O)

(Rawson \& Tupper 1968)

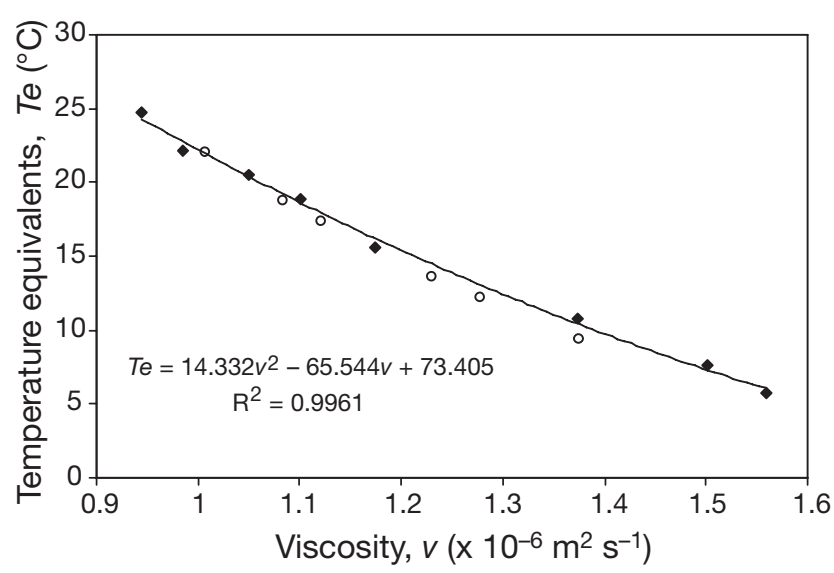

Fig. 3. Temperature data from Fig. 2 as a function of measured kinematic viscosity. Te: temperature equivalents. Symbols as in Fig. 2

$0.61,0.46,0.23$, and $0 \mathrm{~g}$ dextran $\mathrm{l}^{-1}$ were used to manipulate the viscosity of seawater. According to Table 1, $v_{\mathrm{w}}=1.00691 \times 10^{-6} \mathrm{~m}^{2} \mathrm{~s}^{-1}\left(20 \mathrm{psu}, 22^{\circ} \mathrm{C}\right)$.

$\boldsymbol{P V P}$ : The viscosity of seawater in the observation vessel was manipulated by adding polyvinyl pyrrolidone (PVP360 Polyvinylpyrrolidone = Polyvidone = PVP, average mol wt. 360000 ; Sigma-Aldrich). The actual viscosity was determined using a calibrated viscometer (Ubbelohde Viscometer fitted with a tempering jacket; Schott). The effect of added PVP on the kinematic viscosity of seawater is shown in Table 1, which also shows for comparison temperature equivalents of 35 psu seawater, according to Rawson \& Tupper (1968). The effect of salinity was negligible (20 vs. $35 \mathrm{psu})$. Concentrations of $1.2,2.2,3.6,0.5$ and $7.2 \mathrm{~g}$ PVP $\mathrm{l}^{-1}$ were needed to manipulate the viscosity of $22^{\circ} \mathrm{C}$ seawater (20 psu) to those viscosities of seawater at temperatures of $19.2,17.9,14.5,13.1$ and $10.4^{\circ} \mathrm{C}$, respectively. 
Table 1. Effect of added dextran and polyvinyl pyrrolidone (PVP) on measured mean $\left( \pm \mathrm{SD}, \mathrm{n}\right.$ in parentheses) kinematic viscosity of seawater $\left(20 \mathrm{psu}, 22^{\circ} \mathrm{C}\right)$. Temperature equivalents ( $\mathrm{Te}$ ) estimated according to equation shown in Fig. 2, or obtained from table-values of viscosity of seawater (35 psu) vs. temperature given by Rawson \& Tupper (1968)

\begin{tabular}{|lccc|}
\hline $\begin{array}{l}\text { Conc. } \\
\left(\mathrm{g} \mathrm{l}^{-1}\right)\end{array}$ & $\begin{array}{c}\text { Kinematic viscosity } \\
\left(10^{-6} \mathrm{~m}^{2} \mathrm{~s}^{-1}\right)\end{array}$ & $\begin{array}{c}\text { Estimated Te } \\
(20 \mathrm{psu})\left({ }^{\circ} \mathrm{C}\right)\end{array}$ & $\begin{array}{c}\text { Table-values for } \\
\mathrm{Te}(35 \mathrm{psu})\left({ }^{\circ} \mathrm{C}\right)\end{array}$ \\
\hline 0 & $1.0069 \pm 0.0029(4)$ & 21.9 & 22.0 \\
Dextran & $1.1117 \pm 0.0325(6)$ & 18.3 & 17.8 \\
0.23 & $1.1746 \pm 0.0325(6)$ & 16.2 & 15.5 \\
0.46 & $1.2690 \pm 0.0619(6)$ & 13.3 & 12.4 \\
0.61 & $1.4368 \pm 0.0257(6)$ & 8.8 & 7.9 \\
0.68 & $1.6466 \pm 0.0257(6)$ & 4.3 & 18.3 \\
0.75 & & & 17.3 \\
$\mathbf{P V P}$ & $1.0833 \pm 0.0047(4)$ & 19.2 & 13.6 \\
0.12 & $1.1222 \pm 0.0029(4)$ & 17.9 & 9.4 \\
0.22 & $1.2302 \pm 0.0074(4)$ & 14.5 & \\
0.36 & $1.2777 \pm 0.0029(4)$ & 13.1 & \\
0.50 & $1.3757 \pm 0.0055(4)$ & 10.4 & \\
0.72 & & & \\
& & & \\
\hline
\end{tabular}

Effect of viscosity on filtration rate of intact mussels. Blue mussels Mytilus edulis were collected in the southeastern part of Kerteminde Fjord (Fyn, Denmark) in September 2006 and brought to the nearby Marine Biological Research Centre where the experiments were conducted. The filtration rate was measured as the volume of seawater (20 psu) cleared of suspended algal cells Rhodomonas sp. (almost spherical, about $6.3 \mu \mathrm{m}$ in diameter) per unit time using the clearance method (Riisgård 2001b). Algal cells were added to a well-mixed, strongly aerated aquarium with a known volume of seawater $(V=1.5 \mathrm{l})$ and a group $(n=6)$ of mussels. The reduction in the number of algal cells was followed as a function of time by taking samples $(15 \mathrm{ml})$ every $5 \mathrm{~min}$ and measuring the algal concentration with an electronic particle counter (Elzone 5380). After measurement, the remaining water (ca. $13 \mathrm{ml}$ ) was returned to the experimental aquarium to ensure a negligible reduction in the total water volume. The individual filtration rate $(F)$ was determined from the exponential decrease in algal concentration as a function of time using the formula: $F=b V / n$ where $V=$ volume of water, $n=$ number of filtering mussels, and $b=$ slope of the regression line in a semi-ln plot of the reduction in algal concentration with time in the aquarium with mussels. Repeated measurements of filtration rate over time were performed by adding algal suspension to re-establish the initial algal concentration in the aquarium, and the effect of manipulated water viscosity was studied by adding a certain volume of dissolved PVP (10.5 g in $100 \mathrm{ml}$ seawater) to the aquarium in which the water temperature was kept constant at $22^{\circ} \mathrm{C}$ using a cooler/heater system (Lauda). In a control without mussels, there was intact mussel. no significant sedimentation of algal cells. Since suspended algal cells are retained with an efficiency of $100 \%$ by the gills of $M$. edulis (Møhlenberg \& Riisgård 1978), this implies that the measured clearance rate, or filtration rate $(F)$, is equal to the pumping rate. The clearance measurements were conducted at naturally low algal concentrations (i.e. ca. 500 to 4000 Rhodomonas sp. cells $\mathrm{ml}^{-1}$ ), equivalent

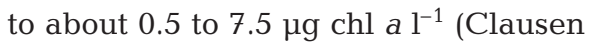
\& Riisgård 1996). After each clearance measurement, the viscosity was measured (Ubbelohde Viscometer) at $22^{\circ} \mathrm{C}$ and expressed as a temperature equivalent (cf. Fig. 3). The mean shell length of the group of mussels used was $32 \pm$ 2.1 (SD) $\mathrm{mm}(\mathrm{n}=6)$.

\section{RESULTS}

We determined (for mussel-gill preparations stimulated with $10^{-5} \mathrm{M} 5-\mathrm{HT}$ ) the beat frequencies of lateral cilia at different dextran-manipulated viscosities of seawater $\left(22^{\circ} \mathrm{C}, 20 \mathrm{psu}\right)$ expressed as temperature equivalents ( $\mathrm{Te}$ ) (Fig. 4, $\square$ ). The viscosity had a pronounced effect on the ciliary beat frequency, which increased in an approximately linear relationship with Te. Also shown in Fig. 4 are similar results for PVPmanipulated viscosities of seawater $(\bigcirc)$, and for changing temperature of seawater $(\diamond)$. The data sets were modelled by linear regression models (Fig. 4). The model slopes for PVP-manipulated viscosities and for temperature-manipulated viscosities are very similar (see equations in Fig. 4), indicating that the effect of temperature on lateral cilia activity in gill-preparations was purely mechanical, controlled by the viscosity of the ambient seawater.

At constant temperature $\left(22^{\circ} \mathrm{C}\right)$, the beat frequency $(f)$ decreased when exposed to increasing dextran- or PVP-manipulated viscosities of the seawater (Fig. 5). It is remarkable that beat frequency was not simply inversely proportional to kinematic viscosity, $v$, but behaved as $f \approx v^{-3 / 2}$, a relationship that we used in the subsequent development of a pump model for the

Fig. 6 shows the exponential decrease in algal cell concentrations as a function of time due to grazing by a group of mussels in an aquarium with well-mixed seawater $\left(22^{\circ} \mathrm{C}\right)$, without and with different concentrations of PVP added in order to manipulate the viscosity. The corresponding filtration rates are shown in Fig. 7. The mussels were fully open in clean seawater and at 


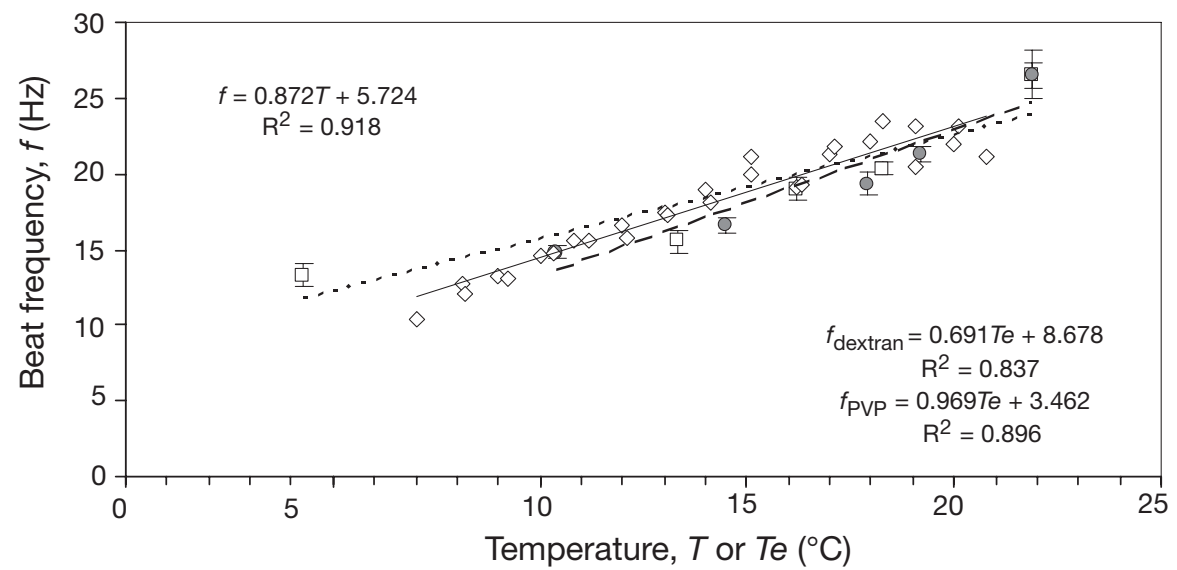

Fig. 4. Mytilus edulis. Beat frequency of lateral cilia in mussel-gill preparations stimulated with $10^{-5} \mathrm{M}$ 5 -HT versus temperature $(T)$ or temperature equivalents $(T e) ;(\diamond)$ exposed to different temperatures of the seawater; ( $\square$ ) exposed to different dextran-manipulated viscosities of seawater $\left(22^{\circ} \mathrm{C}, 20 \mathrm{psu}\right)$; (O) exposed to different PVP-manipulated viscosities of seawater $\left(22^{\circ} \mathrm{C}, 20 \mathrm{psu}\right)$. Mean $( \pm 2 \mathrm{SD}, \mathrm{n}=8)$ indicated for PVP and dextran the 2 lowest PVP-concentrations; but, at the 2 highest PVP-concentrations there was a noticeable effect on the exhalant opening (some constriction), and the mantle edges were pulled inwards. This may have lowered the filtration rates.

The ciliary response (as beat frequency of lateral cilia versus changes in kinematic viscosity determined for mussel-gill preparations) may also be expected to apply to intact mussels, and accordingly we use this assumption in construction of the following musselpump model.

\section{MUSSEL-PUMP MODEL}

To study the effect of viscosity on pumping rate of intact mussels, consider the flow model of Jørgensen et al. (1986), comprising a leaky, viscous pump with an operating pump pressure $\Delta H_{\mathrm{P}}\left(1.38 \mathrm{~mm} \mathrm{H}_{2} \mathrm{O}\right)$, viscous resistances to flow in the interfilament canals $\left(\Delta H_{\mathrm{ifc}}, 0.44\right)$ and in the exhalant siphon $\left(\Delta H_{\mathrm{es}}, 0.14\right)$, a kinetic energy loss at the exit $\left(\Delta H_{\mathrm{ex}}, 0.38\right)$, and resistance due to the

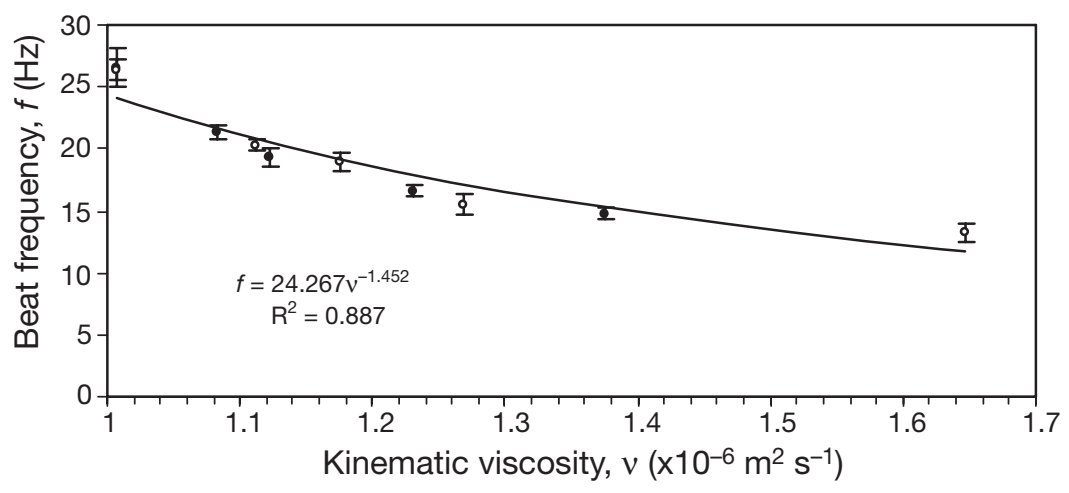

Fig. 5. Mytilus edulis. Mean $( \pm 2 \mathrm{SD}, \mathrm{n}=8$ ) beat frequency of lateral cilia in gill preparations stimulated with $10^{-5} \mathrm{M} 5-\mathrm{HT}$ at constant temperature $\left(22^{\circ} \mathrm{C}\right)$ and exposed to different dextran-manipulated (0) or PVP-manipulated $(\bullet)$ viscosities of the seawater (20 psu). The common power-function line and its equation are shown laterofrontal cirri $\left(\Delta H_{\mathrm{lf}}, 0.4\right)$. According to Jørgensen et al. (1986, Table 3 therein) the percentage contributions of the 4 main components of system resistance $\left(\Delta H_{\mathrm{S}}\right)$ are approximately: $\Delta H_{\text {ifc }}=31 \%, \Delta H_{\mathrm{es}}=10 \%, \Delta H_{\mathrm{ex}}=28 \%$, and $\Delta H_{\mathrm{lf}}=29 \%$ for a '35 mm standard' mussel at the reference temperature of $17^{\circ} \mathrm{C}$. However, for the $10^{-5} \mathrm{M}$ 5-HT stimulated gill-preparation studied in the present work, the frictional loss in the interfilament canal is the only contribution to the system resistance.

According to the usual filter-pump analysis (Riisgård \& Larsen 1995, 2000), the flow adjusts itself so that the pump pressure exactly balances the total resistance of the pump system, that is: $\Delta H_{\mathrm{p}}=\Delta H_{\mathrm{S}}$, where according to Jørgensen et al. (1990, Eqs. 3 to 6 therein):

$$
\begin{aligned}
& \Delta H_{\mathrm{S}}=\Delta H_{\mathrm{ifc}}+\Delta H_{\mathrm{es}}+\Delta H_{\mathrm{ex}}+\Delta H_{\mathrm{lf}}= \\
& C_{1} v V+C_{2} v^{1 / 2} V^{3 / 2}+C_{3} V^{2}+\Delta H_{\mathrm{lf}}
\end{aligned}
$$

Here, $v(=\mu / \rho)$ is the kinematic viscosity, $\mu$ is dynamic viscosity, $\rho$ is the density of seawater (assumed to be constant), and $V$ denotes the pumping rate (the filtration rate, or clearance rate of particles retained by the gills with $100 \%$ efficiency). Constants $C_{1}, C_{2}$ and $C_{3}$ include fixed geometric parameters of the interfilament canal and siphon.

The leaky, viscous gill pump represented by bands of beating lateral cilia is modeled phenomenologically by (Jørgensen et al. 1990, Eq. 7 therein):

$$
V=V_{\mathrm{d}}-V_{\mathrm{l}}
$$

where the net volume flow ( $V=$ pumping rate) equals the difference between the volume flow driven by the cilia $\left(V_{\mathrm{d}}\right)$, and the return flow $\left(V_{1}\right)$ leaking back through the pump. This return flow is proportional to the pressure rise over the pump, $V_{1} \approx \Delta H_{\mathrm{P}}$, so Eq. (2) may be written in the usual form of a pump characteristic: 


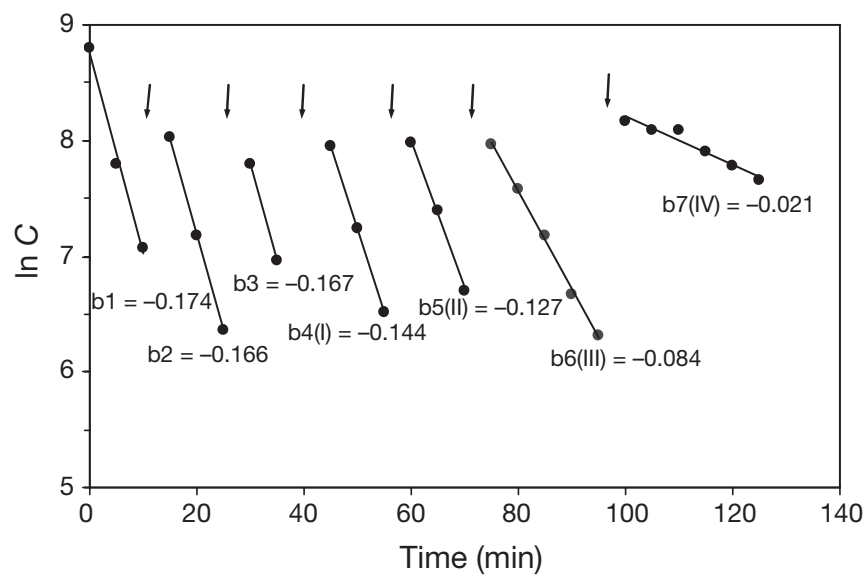

Fig. 6. Mytilus edulis. Exponential decrease in algal cell concentration $\left(C\right.$, cells $\left.\mathrm{ml}^{-1}\right)$ as a function of time due to grazing by a group $(\mathrm{n}=6)$ of mussels at $22^{\circ} \mathrm{C}$ in an aquarium with well-mixed seawater, without (b1, b2, b3) and with different concentrations of PVP (b4, b5, b6, b7) added in increasing concentrations (I, II, III, IV). Regression lines and estimated slopes (b) are shown. Arrows indicate addition of algal cells. Estimated filtration rates are shown in Fig. 7

$$
\Delta H_{\mathrm{P}}=\Delta H_{\mathrm{P}}^{0}\left(1-V / V_{\mathrm{d}}\right) ; \Delta H_{\mathrm{P}}^{0} \equiv C v^{\mathrm{m}} V_{\mathrm{d}}
$$

where $C$ is a constant, and the expression for the maximum pressure at zero pumping, $\Delta H_{\mathrm{P}}{ }^{0}$, is based on experimental observations and on the assumptions that the driving velocity is proportional to the beat frequency of water pumping lateral cilia, $V_{\mathrm{d}} \approx f$, and that $f$ depends only on viscosity of the water, and is not influenced by the added $10^{-5} \mathrm{M} 5$-HT necessary for ensuring a steady lateral ciliary beat frequency in gillpreparations. Thus, as shown experimentally by Jørgensen et al. (1986, Table 2 therein; 1988, Table 2 therein; 1990, Table 3 therein), in fully open mussels, for the 3 cases, $\Delta H_{\mathrm{P}}{ }^{0}$ is essentially constant (about $3.8 \pm$

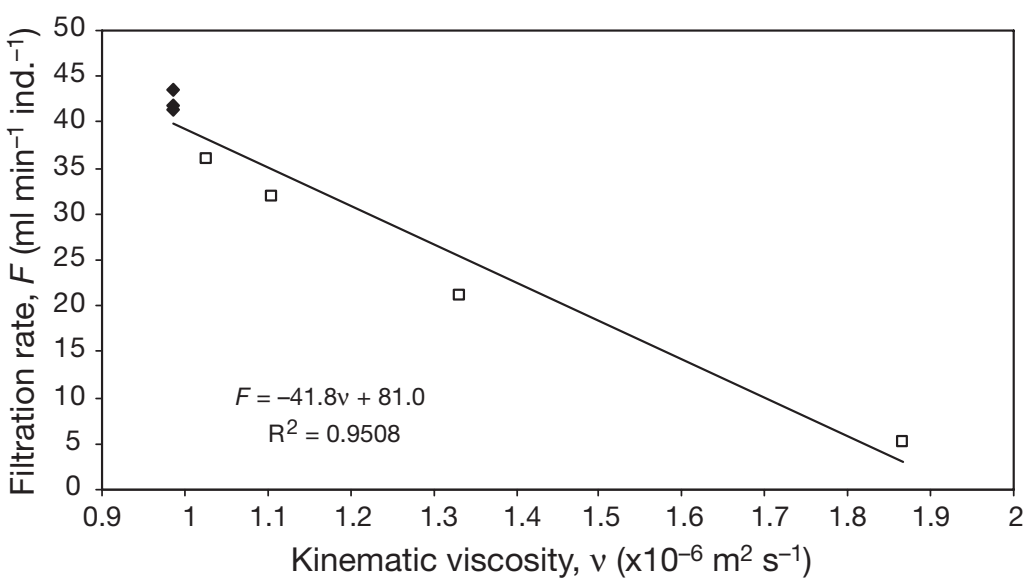

Fig. 7. Mytilus edulis. Relationship between filtration rate of intact mussels at constant temperature $\left(22^{\circ} \mathrm{C}\right)$, exposed $(\square)$ and not exposed $(\diamond)$ to different PVPmanipulated viscosities of seawater (20 psu). Regression line and its equation for all data points are shown
$1.0,3.5 \pm 0.4[3.7 \pm 0.4 ; 5$-HT stimulated $]$, and $3.19 \pm$ $0.32 \mathrm{~mm} \mathrm{H}_{2} \mathrm{O}$, respectively) and independent of temperature. The present data on beat frequency vs. kinematic viscosity in gill-preparations (Fig. 5) suggest $f \approx v^{-m}, m \approx 3 / 2$.

Equating Eqs. (1) and (3) gives:

$$
C v^{\mathrm{m}} V_{\mathrm{d}}\left(1-V / V_{\mathrm{d}}\right)=C_{1} v V+C_{2} v^{1 / 2} V^{3 / 2}+C_{3} V^{2}+\Delta H_{\mathrm{lf}}
$$

which, after dividing by the reference value $\Delta H_{\mathrm{P} \text {, ref }}(=$ $1.38 \mathrm{~mm} \mathrm{H}_{2} \mathrm{O}$ at $17^{\circ} \mathrm{C}$ ), using $v^{\mathrm{m}} V_{\mathrm{d}} \approx v_{\text {ref }} \mathrm{m}^{\mathrm{m}} V_{\mathrm{d} \text {,ref, }}$ and introducing $\tilde{v}=v / \nu_{\text {ref }}$ and $\tilde{V}=V / V_{\text {ref }}$, may be rearranged as

$$
\begin{aligned}
& \left(1-C_{0} \tilde{v}^{\mathrm{m}} \tilde{V}\right) /\left(1-C_{0}\right)= \\
& 0.31 \tilde{v} \tilde{V}+0.10 \tilde{v}^{1 / 2} \tilde{V}^{3 / 2}+0.28 \tilde{V}^{2}+0.29
\end{aligned}
$$

where $C_{0}=V_{\text {ref }} / V_{\mathrm{d} \text {,ref }}$ and the coefficients to terms on the right hand side of Eq. (5) are recognized as the fractions of total head loss given above for the 4 main contributions at the reference state. Clearly, Eq. (5) is identically satisfied at the reference state $(\tilde{v}=1, \tilde{V}=1)$, and it shows how the various contributions to system resistance change as $\tilde{v}$ and $\tilde{V}$ change from their values at the reference state. The constant $C_{0}$ is determined by use of the reference values $\Delta H_{\mathrm{P} \text {, ref }}=1.38 \mathrm{~mm} \mathrm{H}_{2} \mathrm{O}$ and $\Delta H_{\mathrm{P}}{ }^{0} \approx 3.8 \mathrm{~mm} \mathrm{H}_{2} \mathrm{O}$ from Jørgensen et al. (1986), since Eq. (3) evaluated at the reference state gives $V_{\text {ref }} / V_{\mathrm{d}, \text { ref }}=1-\Delta H_{\mathrm{P}, \text { ref }} / \Delta H_{\mathrm{P}}^{0}=1-1.38 / 3.8=0.637$.

The result Eq. (5) is an equation for $\tilde{V}$ as function of $\tilde{v}$, i.e. a quantity proportional to filtration rate, $F$, of an intact mussel vs. kinematic viscosity. Solutions to Eq. (5) at $m=3 / 2$ and scaled to the 3 reference states of $F_{\text {ref }}=34$ (present Fig. 7), 62 (Jørgensen et al. 1990, Fig. 3 therein), and 93.6 (Kittner \& Riisgård 2005, Fig. 2B therein) $\mathrm{ml} \mathrm{min}^{-1}$ ind. ${ }^{-1}$, respectively, all at $v_{\text {ref }}=$ $1.15 \times 10^{-6} \mathrm{~m}^{2} \mathrm{~s}^{-1}\left(17^{\circ} \mathrm{C}\right)$, i.e. setting $F=F_{\text {ref }} \tilde{V} / \tilde{V}_{v=1}$ at each $\tilde{V}$ and $v=v_{\text {ref }} \tilde{V}$ at each corresponding $\tilde{v}$, are shown in Fig. 8 along with linear regression lines in Table 2.

The model results in Fig. 8 for the 3 reference states show general agreement with corresponding measurements on intact mussels given for a $35 \mathrm{~mm}$ mussel (this study) (slope: $-40.7 \pm 4.2$ [SE]), for a $39 \mathrm{~mm}$ mussel (data from Jørgensen et al. 1990, Fig. 3 therein) (slope: $-51.5 \pm$ 5.3) and for a $50 \mathrm{~mm}$ mussel (data from Kittner \& Riisgård 2005, Fig. 2B therein) (slope: $-89.3 \pm 5.1$ ). According to the present model, slopes of regression lines increase linearly with the value of $F_{\text {ref }}$ to which results are scaled, which tends to reflect the trend of the data for the 3 cases, with slopes of $-31.0 \pm 1.2,-56.4$ \pm 2.1 and $-85.2 \pm 3.2$, respectively. It should also be stressed that use of the reference state taken from a given set of data makes the model prediction exactly 


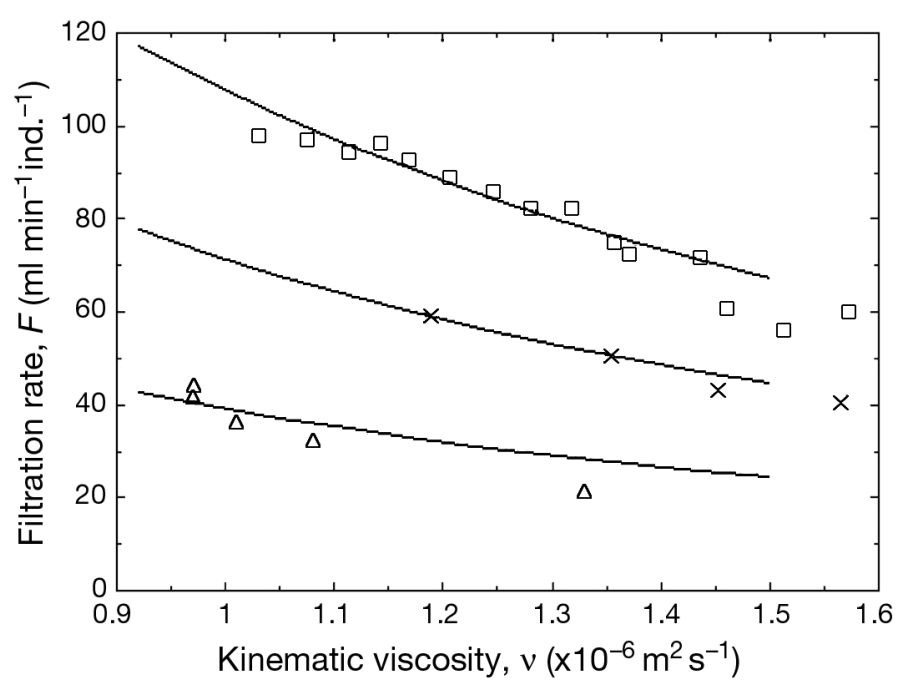

Fig. 8. Mytilus edulis. Experimental data $(\Delta, \times, \square)$ compared to model predictions (curves) of filtration rate vs. kinematic viscosity for intact mussels corresponding to the 3 reference states of $F_{\text {ref }}=34,62$ and $93.6 \mathrm{ml} \mathrm{min}^{-1}$ ind. ${ }^{-1}$, respectively, all at $v_{\text {ref }}=1.15 \times 10^{-6} \mathrm{~m}^{2} \mathrm{~s}^{-1}, 17^{\circ} \mathrm{C}$. Table 2 gives data sources and regression lines fitted to data and model predictions

match the data at this state. However, the main objective of the model was to determine the slope of the $F, v$-curve, which is in no respect an input taken from the data. Also, the 5 constants introduced in Eq. (5) (the ratio $\Delta H_{\mathrm{P}, \mathrm{ref}} / \Delta H_{\mathrm{P}}{ }^{0}$, and the 4 fractions of total head loss from the 4 main contributions) may vary among specimens and by size, but have been kept unchanged for the 3 cases considered, because of lack of information. Within the assumptions mentioned we conclude that the model is able to predict the response of filtration rate of intact mussels to change in viscosity, be it due to temperature change or viscosity-manipulation at constant temperature.

Solutions to Eq. (5) for values other than $m=3 / 2$ show less agreement with available data on filtration rate vs. kinematic viscosity. Specifically, when $m=1$, which would correspond to a linear, viscous pump model, as used in Jørgensen et al. (1990, Eqs. 8 \& 9 therein), the slope values of $F, v$-curves are too small.

In the present pump model, the driving flow, $V_{\mathrm{d}}$, is assumed to be proportional to the beat frequency of lateral cilia, and the average force exerted on the cilia is assumed to increase with increasing viscosity as $v^{m}$ so that the power delivered by the pump is of the form, $P_{\mathrm{P}} \approx v^{\mathrm{m}} V_{\mathrm{d}}$. This expression has the same form as $\Delta H_{\mathrm{P}}{ }^{0}$ in Eq. (3), which according to observations by Jørgensen et al. (1986, Table 2 therein; 1988, Table 2 therein; 1990, Table 3 therein) appears to be approximately constant, hence we conclude that the ciliary mussel pump yields a constant power. Note that this pump power is proportional to the metabolic power expended by the model of the mussel and not the useful power received by the water.

\section{DISCUSSION}

The present study has demonstrated a pronounced effect of viscosity on ciliary beat frequency in mussel-gill preparations (Fig. 4), suggesting the relation $f \approx v^{-3 / 2}$ (Fig. 5). This observation was used to develop a pump model of an intact mussel, based on the further assumptions that (1) the lateral cilia activity is the same in a gillpreparation as in an intact mussel, and (2) that the ciliary driving velocity is proportional to beat frequency, $f$. Possible evidence for the latter assumption comes from Petersen et al. (1999), who measured at different temperatures the beat frequency of the water-pumping lateral stigmatal cilia in an intact ascidian. The beat frequency increased linearly with temperature, and it was closely correlated with the increase in filtration rate. An argument for the former assumption is that the power delivered by the ciliary mussel pump appears to be constant. Petersen et al. (1999) suggested that physiological rather than physico-mechanical mechanisms controlled beat frequency and hence pumping rate, although no observations of response to a viscosity change at constant temperature were made to support this statement.

The present mussel-pump model predicts for 3 sets of experimental data the dependence of filtration rate on kinematic viscosity (Fig. 8). Based on this result, and the closely matching slopes of regression lines in Fig. 4 for the response of ciliary beat frequency in gill preparations to changes in temperature and to changes in viscosity by additives to seawater at constant temperature, we conclude that physical/mechanical factors, rather than biological/physiological mechanisms control the

Table 2. Mytilus edulis. Linear regression of filtration rate $\left(F, \mathrm{ml} \mathrm{min}^{-1}\right.$ ind $\left.{ }^{-1}\right)$ on kinematic viscosity $\left(v, 10^{-6} \mathrm{~m}^{2} \mathrm{~s}^{-1}\right), F=a+b v$, for experimental data and model predictions shown in Fig. 8

\begin{tabular}{|c|c|c|c|c|c|c|}
\hline \multirow{2}{*}{$\begin{array}{l}\text { Shell } \\
\text { length }(\mathrm{mm})\end{array}$} & \multirow{2}{*}{$\begin{array}{l}F_{\text {ref }}\left(\mathrm{ml} \mathrm{min} \mathrm{mind}^{-1} \mathrm{ind}^{-1}\right) \text { at } \\
v_{\text {ref }}=1.15 \times 10^{-6} \mathrm{~m}^{2} \mathrm{~s}^{-1}\end{array}$} & \multicolumn{2}{|c|}{ — Experimental data -} & \multicolumn{2}{|c|}{$\longrightarrow$ Model $\longrightarrow$} & \multirow{2}{*}{ Source } \\
\hline & & $a \pm \mathrm{SE}$ & $b \pm \mathrm{SE}$ & $a \pm \mathrm{SE}$ & $b \pm \mathrm{SE}$ & \\
\hline 35 & 34 & $79.1 \pm 5.3$ & $-40.7 \pm 4.2$ & $69.9 \pm 1.4$ & $-31.0 \pm 1.2$ & Present study, Fig. 7 \\
\hline 39 & 62 & $119.9 \pm 7.4$ & $-51.5 \pm 5.3$ & $127.5 \pm 2.6$ & $-56.4 \pm 2.1$ & Jørgensen et al. (1990) \\
\hline 50 & 93.6 & $195.8 \pm 6.7$ & $-89.3 \pm 5.1$ & $192.5 \pm 3.9$ & $-85.2 \pm 3.2$ & Kittner \& Riisgård (2005) \\
\hline
\end{tabular}


filtration rate of mussels and possibly other ciliary suspension-feeding organisms. In mussels and other bivalves with compound eulaterofrontal cirri, the so-called 'cirral particle trapping mechanism' operates (Riisgård et al. 1996, Riisgård \& Larsen 2005), and mucus is not involved in either the particle capture process or the subsequent transport of captured particles towards the mouth. But at high silt concentrations ( $>1 \mathrm{mg}$ silt $\mathrm{l}^{-1}$ ), Mytilus edulis, for example, produces mucus for cleaning the overloaded gill. Here, a mixture of food and silt particles enrolled in mucus is carried to the labial palps where the food particles are sorted from the silt particles, which are subsequently rejected along with the mucus as pseudofaeces (Jørgensen 1990). In the present work, the addition of PVP did not cause production of pseudofaeces, and since the measurement of filtration rate of mussels is based on the clearance method, we also conclude that the particle-capture process itself (in this case involving only one particle size) is apparently not affected adversely by temperature or viscosity, as found by Podolsky (1994) and Bolton \& Havenhand (1998), who considered a range of particle sizes and species. Further, it may be concluded that the ciliary mussel pump not only yields a constant power within the temperaturetolerance interval, but apparently, to judge from the lack of temperature compensation in mussels (Kittner \& Riisgård 2005), the performance of the mussel pump also remains constant following transfer to a higher or lower constant temperature.

The general lack of temperature compensation in ciliary suspension-feeding bivalves (Kittner \& Riisgård 2005) shows that the beat frequency of the lateral cilia is not likely to be adjusted as a regulatory response to ambient temperature. In aquatic invertebrates, the oxygen consumption rate (respiration rate) behaves like that of an in vitro biochemical system, and typically doubles with every $10^{\circ} \mathrm{C}$ increase in temperature (van't Hoff's rule), which implies that the change of respiration rate $(R)$ with increasing temperature is exponential, a relationship which is usually described mathematically by the function $Q_{10}=\left(R_{2} / R_{1}\right)^{10 /(t 2-t 1)}$, where $R_{2}$ and $R_{1}$ are the respiration rates at 2 temperatures, $t_{2}$ and $t_{1}$ (Schmidt-Nielsen 1970). The filtration rate in ciliary suspension-feeding invertebrates is another important physiological function, but although a 'filtration rate $Q_{10}{ }^{\prime}$ is frequently reported in the literature (e.g. Widdows \& Bayne 1971, McLusky 1973, Bayne et al. 1976, Lei et al. 1996, Yukihira et al. 2000, Petersen et al. 2003), a number of recent studies show that the concept is inappropriately applied to these animals, because it is the temperature-dependent viscosity of the ambient water that mechanically controls the beat frequency of the water pumping cilia and thus the filtration rate. This statement is supported by a number of studies showing that the relationship between filtration rate and temperature is linear (not exponential) in ciliary suspension-feeding invertebrates, e.g. in the sponge Halichondria panicea (Riisgård et al. 1993), the polychaete Sabella penicillus (Riisgård \& Ivarsson 1990), the bryozoans Electra pilosa, Conopeum reticulatum (Menon 1974), Celleporella hyalina (Riisgård \& Manríques 1997), the mussel Mytilus edulis (Jørgensen et al. 1990, Kittner \& Riisgård 2005), the soft clam Mya arenaria (Riisgård \& Seerup 2003), and the ascidian Ciona intestinalis (Petersen \& Riisgård 1992).

It seems unlikely that the filtration rate of bivalves may be physiologically regulated by adjustment of the lateral ciliary beat frequency. Thus, higher or lower filtration rates may be gained only through an evolutionary change in cilia length, or increase/ decrease of the total length of the lateral ciliary band. The latter hypothesis is illustrated by the following example.

In the scallop Aequipecten opercularis, the total length of the lateral ciliary band is $446 \mathrm{~m} \mathrm{~g}^{-1}$, and the filtration rate is $10.7 \mathrm{l} \mathrm{h}^{-1} \mathrm{~g}^{-1}$, giving a length-specific filtration rate for the lateral ciliary band of $0.24 \mathrm{ml} \mathrm{h}^{-1}$ $\mathrm{cm}^{-1}$ (Riisgård \& Larsen 2005). These values may be compared to similar data obtained for Mytilus edulis (Table 3). The weight-specific filtration rate is nearly twice as high in A. opercularis and the total length of the lateral ciliary band is 2.8 times longer, whereas the length specific filtration rate is somewhat lower. Because the length of the lateral cilia is $15 \mu \mathrm{m}$ in both species, this supports the hypothesis that $A$. opercularis may have evolved to subsist at lower algal concentrations (in deeper water) than $M$. edulis by a conspicuous increase of the total length of the water pumping lateral ciliary band. Table 4 shows the increase in lateral ciliary beat frequency with temperature (i.e. decreasing viscosity) in different marine bivalves and the ascidian Ciona intestinalis. Most of the data indicate an increase in beat frequency with temperature on the order of 0.7 to $0.9 \mathrm{~Hz} /{ }^{\circ} \mathrm{C}$, but larger values appear in some species. Such differences may

Table 3. Weight specific filtration rate $(F)$, total length of lateral ciliary band per $g$ dry body weight $\left(T_{\mathrm{lc}}\right)$, and lengthspecific filtration rate of lateral ciliary band $\left(F_{1 \mathrm{~s}}\right)$. ${ }^{\mathrm{a}}$ Data from Riisgård \& Larsen (2005); ' bauthors' unpublished data on gills combined with $5^{\circ} \mathrm{C}$ temperature-corrected (Kittner \& Riisgård 2005) filtration rate obtained from Møhlenberg \& Riisgård (1979)

\begin{tabular}{|lccc|}
\hline Species & $\begin{array}{c}F \\
\left(\mathrm{~h}^{-1} \mathrm{~g}^{-1}\right)\end{array}$ & $\begin{array}{c}T_{\mathrm{lc}} \\
\left(\mathrm{cm} \mathrm{g}^{-1}\right)\end{array}$ & $\begin{array}{c}F_{\mathrm{ls}} \\
\left(\mathrm{ml} \mathrm{h}^{-1} \mathrm{~cm}^{-1}\right)\end{array}$ \\
\hline Aequipecten opercularis $^{\mathrm{a}}$ & 10.7 & 44583 & 0.24 \\
Mytilus edulis $^{\mathrm{b}}$ & 5.53 & 15851 & 0.35 \\
\hline
\end{tabular}


Table 4. Increase in lateral ciliary beat frequency with temperature in different marine bivalves and the ascidian Ciona intestinalis

\begin{tabular}{|c|c|c|c|}
\hline Species & Comments & $\begin{array}{l}\text { Slope of regression line } e^{\mathrm{a}} \text { or } \\
\text { increase in beat frequency } \\
\text { with temperature (or temp. } \\
\left.\quad \text { equivalent } \mathrm{t}^{\mathrm{b}}\right)\left(\mathrm{Hz} /{ }^{\circ} \mathrm{C}\right)\end{array}$ & Source \\
\hline Mytilus edulis & Gill preparation & $\begin{array}{l}(10.4-6.8) /(10-2)=0.45 \\
(22-10.4) /(23-10)=0.89\end{array}$ & Aiello (1960) \\
\hline Modiolus modiolus & Gill preparation $+10^{-5} \mathrm{M} 5 \mathrm{HT}$ & $(31-15.7) /(21-11)=1.53$ & $\begin{array}{l}\text { Jørgensen } \\
\text { et al. (1990) }\end{array}$ \\
\hline Mytilus edulis & Intact, young transparent mussel & $(14-9) /(20.5-14)=0.77$ & $\begin{array}{l}\text { Jørgensen \& } \\
\text { Ockelmann (1990) }\end{array}$ \\
\hline Abra nitida & Intact, young transparent mussel & $(15-10) /(20.5-14)=0.77$ & $\begin{array}{l}\text { Jørgensen \& } \\
\text { Ockelmann (1990) }\end{array}$ \\
\hline Abra alba & Intact, young transparent mussel & $\begin{array}{l}(19-10.5) /(20.5-14)=1.30 \\
(14-10.5) /(20.5-14)=0.54\end{array}$ & $\begin{array}{l}\text { Jørgensen \& } \\
\text { Ockelmann (1990) }\end{array}$ \\
\hline Spisula subtruncata & Intact, young transparent mussel & $(20.5-12.8) /(20.5-14)=1.19$ & $\begin{array}{l}\text { Jørgensen \& } \\
\text { Ockelmann (1990) }\end{array}$ \\
\hline Corbula gibba & Intact, young transparent mussel & $(19.5-10) /(20.5-14)=1.46$ & $\begin{array}{l}\text { Jørgensen \& } \\
\text { Ockelmann (1990) }\end{array}$ \\
\hline Cultellus pellucidus & Intact, young transparent mussel & $\begin{array}{l}(19.8-13.5) /(20.5-14)=0.97 \\
(15.1-10.2) /(20.5-14)=0.75\end{array}$ & $\begin{array}{l}\text { Jørgensen \& } \\
\text { Ockelmann (1990) }\end{array}$ \\
\hline Mytilus edulis & Gill preparation $+10^{-5} \mathrm{M} 5 \mathrm{HT}$ & $0.87^{\mathrm{a}}$ & Present study; Fig. 4 \\
\hline Mytilus edulis & Gill preparation $+10^{-5} \mathrm{M} 5 \mathrm{HT}+\operatorname{dextran}\left(22^{\circ} \mathrm{C}\right)$ & $0.66^{\mathrm{b}}$ & Present study; Fig. 4 \\
\hline Mytilus edulis & Gill preparation $+10^{-5} \mathrm{M} 5 \mathrm{HT}+\operatorname{PVP}\left(22^{\circ} \mathrm{C}\right)$ & $0.97^{\mathrm{b}}$ & Present study; Fig. 4 \\
\hline Ciona intestinalis & Intact ascidian & $0.70^{\mathrm{a}}$ & Petersen et al. (1999) \\
\hline
\end{tabular}

be a result of differences in the way viscosity affects the pumping performance due to differences in pump morphology.

Acknowledgements. Thanks to C. Kittner for technical assistance, and 2 anonymous referees for constructive comments on the manuscript. H.U.R. was supported by a grant from the Danish Natural Science Research Council (Grant No. 21-030481).

\section{LITERATURE CITED}

Aiello EL (1960) Factors affecting ciliary activity on the gill of the mussel Mytilus edulis. Physiol Zool 33:120-135

Bayne BL (1998) The physiology of suspension feeding by bivalve molluscs: an introduction to the Plymouth 'TROPHEE' workshop. J Exp Mar Biol Ecol 219:1-19

Bayne, BL, Bayne TC, Carefoot TC, Thomsen RJ (1976) The physiological ecology of Mytilus californuanus Conrad. 1. Metabolism and energy balance. Oecologia 22:211-228

Bolton TF, Havenhand JN (1998) Physiological versus viscosity-induced effects on an acute reduction in water temperature on microsphere ingestion by trochophore larvae of the serpulid polychaete Galeolaria caespitosa. J Plank Res 20:2153-2164

Clausen I, Riisgård HU (1996) Growth, filtration and respiration in the mussel Mytilus edulis: no evidence for physiological regulation of the filter-pump to nutritional needs. Mar Ecol Prog Ser 141:37-45

Jørgensen CB (1975). On gill function in the mussel Mytilus edulis L. Ophelia 13:187-232

Jørgensen CB (1983) Fluid mechanical aspects of suspension feeding. Mar Ecol Prog Ser 11:89-103

Jørgensen CB (1990) Bivalve filter feeding: hydrodynamics, bioenergetics, physiology and ecology. Olsen \& Olsen, Fredensborg

Jørgensen CB, Ockelmann K (1991) Beat frequency of lateral cilia in intact filter feeding bivalves: effect of temperature. Ophelia 33:67-70

Jørgensen CB, Famme P, Kristensen HS, Larsen PS, Møhlenberg F, Riisgård HU (1986) The bivalve pump. Mar Ecol Prog Ser 34:69-77

Jørgensen CB, Larsen PS, Møhlenberg F, Riisgård HU (1988) The mussel pump: properties and modelling. Mar Ecol Prog Ser 45:205-216

Jørgensen CB, Larsen PS, Riisgård HU (1990) Effects of temperature on the mussel pump. Mar Ecol Prog Ser 64:89-97

Kittner C, Riisgård HU (2005) Effect of temperature on filtration rate in the mussel Mytilus edulis: no evidence for temperature compensation. Mar Ecol Prog Ser 305:147-152

Lei J, Payne BS, Wang SY (1996) Filtration dynamics of the zebra mussel, Dreissena polymorpha. Can J Fish Aquat Sci 53:29-37

McLusky DS (1973) The effect of temperature on the oxygen consumption and filtration rate of Chlamys (Aequipecten) opercularis (L.) (Bivalvia). Ophelia 10:141-154

Menon NR (1974) Clearance rates of food suspension and food passage rates as a function of temperature in two North-Sea bryozoans. Mar Biol 24:65-67

Møhlenberg F, Riisgård HU (1978) Efficiency of particle retention in 13 species of suspension feeding bivalves. Ophelia 17:239-246

Møhlenberg F, Riisgård HU (1979) Filtration rate, using a new indirect technique, in thirteen species of suspension-feeding bivalves. Mar Biol 54:143-147

Nielsen NF, Larsen PS, Riisgård HU, Jørgensen CB (1993) Fluid motion and particle retention in the gill of Mytilus edulis: video recordings and numerical modelling. Mar Biol 116:61-71 
Petersen JK, Riisgård HU (1992) Filtration capacity of the ascidian Ciona intestinalis and its grazing impact in a shallow fjord. Mar Ecol Prog Ser 88:9-17

Petersen JK, Mayer S, Knudsen MÅ (1999) Beat frequency of cilia in the branchial basket of the ascidian Ciona intestinalis in relation to temperature and algal cell concentration. Mar Biol 133:185-192

Petersen JK, Sejr MK, Larsen JEN (2003) Clearance rates in the Arctic bivalves Hiatella arctica and Mya sp. Polar Biol 26:334-341

Podolsky RD (1994) Temperature and water viscosity: physiological versus mechanical effects on suspension feeding. Science 265:100-103

Purcell EM (1977) Life at low Reynolds number. Am J Phys 45: $3-11$

Rawson KJ, Tupper EC (1968) Basic ship theory. American Elsevier, New York

Riisgård HU (2001a) Physiological regulation versus autonomous filtration in filter-feeding bivalves: starting points for progress. Ophelia 54:193-209

Riisgård HU (2001b) On measurement of filtration rates in bivalves - the stony road to reliable data: review and interpretation. Mar Ecol Prog Ser 211:275-291

Riisgård HU, Ivarsson NM (1990) The crown-filament pump of the suspension-feeding polychaete Sabella penicillus: filtration, effects of temperature, and energy cost. Mar Ecol Prog Ser 62:249-257

Riisgård HU, Larsen PS (1995) Filter-feeding in marine macroinvertebrates: pump characteristcs, modelling and energy cost. Biol Rev 70:67-106

Riisgård HU, Larsen PS (2000) Comparative ecophysiology of active zoobenthic filter feeding, essence of current knowledge. J Sea Res 44:169-193

Riisgård HU, Larsen PS (2005) Water flow analysis and par-

Editorial responsibility: Howard Browman (Associate Editorin-Chief), Storebø, Norway ticle capture in ciliary filter-feeding scallops (Pectinidae). Mar Ecol Prog Ser 303:177-193

Riisgård HU, Manríquez P (1997) Filter-feeding in fifteen marine ectoprocts (Bryozoa): particle capture and water pumping. Mar Ecol Prog Ser 154:223-239

Riisgård HU, Seerup DF (2003) Filtration rates in the soft clam Mya arenaria: effects of temperature and body size. Sarsia 88:415-428

Riisgård HU, Thomassen S, Jakobsen H, Weeks JM, Larsen PS (1993) Suspension feeding in marine sponges Halichondria panicea and Haliclona ureolus: effects of temperature on filtration rate and energy cost of pumping. Mar Ecol Prog Ser 96:177-188

Riisgård HU, Larsen PS, Nielsen NF (1996) Particle capture in the mussel Mytilus edulis: the role of latero-frontal cirri. Mar Biol 127:259-266

Schmidt-Nielsen K (1970) Animal physiology. Prentice-Hall, Englewood Cliffs, NJ

Sleigh MA (1989) Adaptations of ciliary systems for the propulsion of water and mucus. Comp Biochem Physiol A 94:359-364

Widdows J (1976) Physiological adaptation of Mytilus edulis to cyclic temperatures. J Comp Physiol 105:115-128

Widdows J (1978) Combined effects of body size, food concentration and season on the physiology of Mytilus edulis. J Mar Biol Assoc UK 58:109-124

Widdows J, Bayne BL (1971) Temperature acclimation of Mytilus edulis with reference to its energy budget. J Mar Biol Assoc UK 51:827-843

Yukihira H, Lucas JS, Klumpp DW (2000) Comparative effects of temperature on suspension feeding and energy budgets of the pearl oysters Pinctada margaritifera and P. maxima. Mar Ecol Prog Ser 195:179-188

Submitted: November 28, 2006; Accepted: February 18, 2007 Proofs received from author(s): July 21, 2007 